\title{
Biological characterization of induced phages from Saccharopolyspora hirsuta 367 and comparison with phage JHJ-1
}

\author{
luc R. Gaudreau, Jean M. Lavoie and Claude V. Déry* \\ Groupe de Recherche en Biologie des Actinomycètes, Département de Biologie, Faculté des Sciences, \\ Université de Sherbrooke, Sherbrooke, Québec JIK 2RI, Canada
}

(Received 23 July 1990; revised 24 May 1991; accepted 5 June 1991)

\begin{abstract}
Phages JHJ-2 and JHJ-3 were isolated from Saccharopolyspora hirsuta 367 UC 8106 following induction with mitomycin C and amplified on S. hirsuta NRRL B-5792. Their properties were compared with those of phage JHJ1, isolated previously from $S$. hirsuta 367 NRRL 12045. The DNA restriction patterns appeared to be identical. One-step growth experiments showed no differences between the replication cycles. Burst sizes ranged from 100 to 110 p.f.u. per cell. However, the three phages showed some differences in their behaviour in different hosts. The host range of phage JHJ-1, on non-lysogenic strains, was emended to include all of the Saccharopolyspora strains tested; the host range of phage JHJ-2 was shown to be identical to JHJ-1. Phage JHJ-3 did not form detectable plaques on strains of $S$. rectivirgula or $S$. erythraea except $S$. erythraea NRRL 2359. Neither phage JHJ-2 nor JHJ-3 formed plaques on any lysogenic strains, while $\mathbf{J H J}-1$ formed plaques on all such strains except $S$. hirsuta 367 UC 8106. Phage JHJ-3 was characterized as a temperate bacteriophage because it formed turbid, self-limiting plaques and lysogenized $S$. hirsuta NRRL B-5792. It was spontaneously released from UC 8106. Both JHJ-1 and JHJ-2 formed clear and invasive (Inv ${ }^{+}$phenotype: the property to grow on old mycelium) plaques on some Saccharopolyspora strains but clear and self-limiting plaques on others. Thus, the expression of the Inv ${ }^{+}$phenotype encoded by JHJ-1 and JHJ-2 appears to be modulated by the host cell.
\end{abstract}

\section{Introduction}

The genus Saccharopolyspora includes species such as $S$. erythraea, the producer of the clinically important antibiotic erythromycin (Labeda, 1987) and S. rectivirgula (formerly Faenia rectivirgula; Korn-Wendisch et al., 1989), a causative agent of farmer's lung disease (Pepys et al., 1963; Kurup, 1984). Phages infecting these species have been isolated from lysogenic strains, soils or fermenter cultures and characterized for their potential use as cloning vectors and for studying phage evolution (Brzezinski et al., 1986; Donadio et al., 1986; Grund \& Hutchinson, 1987; Schneider et al., 1987; Katz et al., 1988; Smorawinska et al., 1988; Schneider \& Kutzner, $1989 a, b)$.

Phage JHJ-1 is a lambdoid phage which has doublestranded DNA with cohesive ends. It was spontaneously released by old mycelial cultures of $S$. hirsuta 367 NRRL 12045 (Haket et al., 1990). This phage forms invasive plaques (the ability to grow on old mycelium), a property not previously described in the literature. Host range studies showed that JHJ-1 forms plaques on only two strains, $S$. hirsuta NRRL B-5792 and $S$. hirsuta 367 IC-
11. The latter strain is a derivative of $S$. hirsuta 367 NRRL 12045 (Haket et al., 1990). The spontaneous release of phages resembling phage JHJ-1 was shown to occur infrequently from $S$. hirsuta 367 IC-11 but did not occur from $S$. hirsuta 367 UC 8106, which is another representative of $S$. hirsuta 367 from a different culture collection.

Both S. hirsuta 367 UC 8106 and NRRL 12045 (and IC-11) harbour intracellular DNA homologous to phage JHJ-1 DNA and thus appear to carry a prophage (Haket et al., 1990). However, phage JHJ-1 cannot form plaques on $S$. hirsuta 367 UC 8106 from which $S$. hirsuta 367 NRRL 12045 (and IC-11) was derived earlier (Whaley et al., 1980). One explanation for these data was that JHJ-1 is a virulent mutant of a temperate phage that could infect one lysogen but not the other (Haket et al., 1990). In this paper we describe properties of phages JHJ-2 and JHJ-3 which are released from $S$. hirsuta 367 UC 8106 after induction with mitomycin $\mathrm{C}$. These are compared to phage $\mathrm{JHJ}-1$ at the level of their host range, plaque morphology, burst size and DNA restriction patterns. 
Table 1. Actinomycete strains used in this study

\begin{tabular}{|c|c|c|}
\hline Species & Strain* & Source/reference \\
\hline \multicolumn{3}{|l|}{ Saccharopolyspora } \\
\hline S. hirsuta 367 & UC $8106(\mathrm{JHJ}-3)$ & The Upjohn Company, Kalamazoo, MI, USA \\
\hline S. hirsuta 367 & IC-11 (JHJ-3) & Haket et al. (1990) \\
\hline S. hirsuta & NRRL B-5792† & A. J. Lyons, NRRL, Peoria, IL, USA \\
\hline S. hirsuta & A1143† (= NRRL B-5792†) & $\begin{array}{l}\text { J. Lacey, AFRC Institute of Arable Crops } \\
\text { Research, Herts, UK }\end{array}$ \\
\hline S. hirsuta & B5792LA (JHJ-3) & This study \\
\hline S. hirsuta & B5792LB (JHJ-3) & This study \\
\hline S. erythraea & ATCC $11635 \dagger$ & \\
\hline S. erythraea & NRRL $2338+(=$ ATCC $11635 \dagger)$ & \\
\hline S. erythraea & ISP $5517 \dagger(=$ ATCC $11635 \dagger)$ & R. Brzezinski, University of Sherbrooke, Canada \\
\hline S. erythraea & NRRL 2359 & \\
\hline S. erythraea & NRRL 2360 & \\
\hline S. erythraea & IA 3038 & R. Brzezinski \\
\hline S. rectivirgula & DSM $43787 \dagger$ & $\begin{array}{l}\text { J. Schneider, Institut für Mikrobiologie, } \\
\text { Darmstadt, Germany }\end{array}$ \\
\hline S. taberi & NRRL B-16173† & D. P. Labeda, NRRL, Peoria, IL, USA \\
\hline \multicolumn{3}{|l|}{ Streptomyces } \\
\hline Str. lividans & TK 24 & D. Hopwood, John Innes Institute, Norwich, UK \\
\hline Str. albus & $\mathrm{J} 1074$ & D. Hopwood \\
\hline Str. coelicolor & $\mathrm{A} 3(2)$ & D. Hopwood \\
\hline Str. labedae & NRRL B-5616 & \\
\hline Str. hygroscopicus & NRRL 2387 & \\
\hline Pseudonocardia thermophila & ATCC 19285 & \\
\hline Amycolatopsis orientalis & NRRL B-3892 & \\
\hline
\end{tabular}

* ATCC, American Type Culture Collection, Rockville, MD 20852, USA; NRRL, Northern Regional Research Laboratory, US Department of Agriculture, Peoria, IL, USA.

$†$ Type culture.

\section{Methods}

Bacterial strains and phages. The Saccharopolyspora strains used in this work are listed in Table 1. S. hirsuta 367 UC 8106 (Whaley et al., 1980) was provided by the Upjohn Company (Kalamazoo, MI, USA). This strain was sent to NRRL, where it was given the designation NRRL 12045. Since the stock of $S$. hirsuta 367 NRRL 12045 spontaneously released phages at a rather high frequency, a subclone of this strain, named $S$. hirsuta 367 IC-11, was isolated for the propagation and plating studies of phage JHJ-1 (Haket et al., 1990). $S$. hirsuta 367 IC-11 was shown to spontaneously release phage at a lower frequency but otherwise behaved as the parent strain $S$. hirsuta 367 NRRL 12045. Although $S$. hirsuta 367 UC 8106 and IC-11 are representatives of the same strain, they behave differently in regard to JHJ-1 phage infection (Haket et al., 1990). S. hirsuta NRRL B-5792, the type strain, was used for the propagation of phage JHJ-1 and other phages isolated during this study, since it does not contain DNA homologous to phage $\mathrm{JHJ}-1$.

Since the two strains of $S$. hirsuta 367 (UC 8106 and IC-11) showed differences in sensitivity to JHJ-1 infection (Haket et al., 1990), replicates of the same strains from different culture collections $(S$. hirsuta NRRL B-5792 and A1 143 as well as S. erythraea ATCC 11635, NRRL 2338 and ISP 5517) were also investigated for their response to phage infections. Phenotypic differences have been observed between S. erythraea ATCC 11635 and NRRL 2338 (Paulus et al., 1990).

Media, buffers and chemicals. Medium $\mathrm{W}$ and the phage buffer, which were used for phage titration, amplification, host range and onestep growth experiments, were prepared as described previously
(Haket et al., 1990). Medium WM comprised medium W supplemented with $10 \mathrm{mM}-\mathrm{MgCl}_{2}$. The restriction endonucleases used in this work, BamHI, BclI, BglII, BstBI, NarI, PstI, PvuI, PvuII, SmaI and SphI, were used according to the manufacturer's recommendations. Mitomycin $\mathrm{C}$ was obtained from Boehringer Mannheim.

Induction of the prophages with mitomycin $C$. Actinophage induction from $S$. hirsuta 367 UC 8106 was performed as described by Ogata et al. (1985) with minor modifications. A mycelial culture of $S$. hirsuta 367 UC 8106 was washed in fresh medium $W$, resuspended in preheated medium $\left(30^{\circ} \mathrm{C}\right)$ and was incubated in the absence or presence of mitomycin $\mathrm{C}$ for $1 \mathrm{~h}$. Concentrations up to $50 \mu \mathrm{g} \mathrm{ml}^{-1}$ were used. The cultures were washed, resuspended in fresh medium $\mathrm{W}$ and incubated overnight at $30^{\circ} \mathrm{C}$. The cultures were then centrifuged and the supernatants stored at $4{ }^{\circ} \mathrm{C}$. An aliquot $(1 \mathrm{ml})$ of the supernatants was used to assay the induced phages on plates inoculated with heatshocked $\left(55^{\circ} \mathrm{C}, 10 \mathrm{~min}\right)$ spores of $S$. hirsuta NRRL B-5792 and mycelial cultures of $S$. hirsuta 367 IC-11. After $2 \mathrm{~d}$ incubation, several turbid plaques were picked from B-5792 infected plates, eluted in phage buffer and then amplified on S. hirsuta NRRL B-5792. Two induced phages, named $\mathrm{JHJ}-2$ and $\mathrm{JHJ}-3$, were shown to be phenotypically different after amplification on B-5792 and were therefore characterized further.

Detection of the spontaneous release of phage by S. hirsuta 367 UC8106 and $I C$-1I. A double-overlay assay was developed in order to increase the sensitivity of detection of spontaneously released phage. Mycelial cultures were heavily inoculated into $4 \mathrm{ml}$ soft agar in medium WM and incubated for $2 \mathrm{~d}$ at $30^{\circ} \mathrm{C}$. A second overlay containing $S$. hirsuta NRRL B-5792, the amplification strain, was then deposited and the 
plates were incubated at $30^{\circ} \mathrm{C}$. The phenotype of the plaques was not easy to determine, particularly on the plates inoculated with UC 8106 in the first overlay. Plaques were therefore picked as soon as they appeared, eluted in phage buffer and plated onto strains lysogenized by phage JHJ-3, i.e. S. hirsuta 367 IC-11, UC 8106 and B5792LB (a lysogen of B-5792 isolated in this study), and a non-lysogenic strain, $S$. hirsuta NRRL B-5792, to determine both their sensitivity to phage infection and the plaque morphology.

Phage amplification, purification and host range determination. Phage $\mathrm{JHJ}-1$ and one of the mitomycin $\mathrm{C}$ induced phages, $\mathrm{JHJ}-2$ were amplified on plates and purified as described by Haket et al. (1990) except that the phages were amplified on mycelial cultures of $S$. hirsuta NRRL B-5792 rather than S. hirsuta 367 IC-11.

For the propagation of the other mitomycin $\mathrm{C}$ induced phage, JHJ-3, particles of one turbid plaque were eluted for $8-16 \mathrm{~h}$ at $4^{\circ} \mathrm{C}$ in $100 \mu \mathrm{l}$ of phage buffer and plated on heat-shocked $\left(55^{\circ} \mathrm{C}, 10 \mathrm{~min}\right)$ spores of $S$. hirsuta NRRL B-5792. After $2 \mathrm{~d}$ incubation, ten turbid plaques were picked and eluted in phage buffer (total volume $1 \mathrm{ml}$ ). Heat-shocked spores $\left(10^{7}\right)$ of $S$. hirsuta NRRL B-5792 were inoculated into $100 \mathrm{ml}$ of liquid medium $W$ and incubated for $5-6 \mathrm{~h}$ to allow germination. The culture was then centrifuged $(1000 \mathrm{~g})$, the pellet (germinated spores) resuspended in $10 \mathrm{ml}$ fresh medium $\mathrm{WM}$ and the plaque-purified particles of phage JHJ-3 added. After 30 min incubation to allow phage adsorption, $40 \mathrm{ml}$ medium $\mathrm{W}$ was added and the culture was incubated for $16 \mathrm{~h}$. After centrifugation $(1000 \mathrm{~g})$ the phages were purified from the supernatant by polyethylene glycol 8000 precipitation and $\mathrm{CsCl}$ gradient centrifugation (Haket et al., 1990). These conditions preserved the temperate phenotype of phage JHJ-3 and avoided the selective amplification of $\mathrm{JHJ}$-2-type phages.

For a rapid determination of the host range, $1-2 \mu$ phage stock was spotted onto a lawn of either heat-shocked spores (Grund \& Hutchinson, 1987; Haket et al., 1990) or with S. hirsuta 367 strains UC 8106 and IC-11 on a lawn of mycelial culture. The strains that showed evidence of lysis on the spot tests were assayed with phage dilutions to allow visualization of isolated plaques. Unless otherwise stated, all the incubations were carried out at $30^{\circ} \mathrm{C}\left(43^{\circ} \mathrm{C}\right.$ for $S$. rectivirgula; Smorawinska $e t$ al., 1988) and the liquid cultures were agitated at 250 r.p.m. in a gyratory shaker.

Isolation and characterization of strains lysogenized by phage JHJ-3. S. hirsuta NRRL B-5792 was infected with JHJ-3 to obtain a confluent infection; two resistant colonies were purified by two cycles of amplification in liquid medium $W$ and streaked onto medium $W$ plates in order to isolate single colonies. The phenotypes of these strains, named B5792LA and B5792LB, were confirmed by plating them with diluted suspensions of the three phages in order to visualize individual plaques. The plates were incubated and examined daily for $5 \mathrm{~d}$.

One-step growth experiment of phages $J H J-1, J H J-2$ and $J H J-3$. A onestep growth experiment was performed by a modification of the method described by Dowding (1973). Briefly, $6 \times 10^{7}$ heat-shocked spores of $S$. hirsuta NRRL B-5792 were incubated for $6 \mathrm{~h}$ in medium W to allow germination. The culture was centrifuged and the pellets containing the germinated spores were resuspended in $1 \mathrm{ml}$ medium WM to which $6 \times 10^{6}$ p.f.u. of JHJ-1, JHJ-2 or JHJ-3 were added. After $30 \mathrm{~min}$ of adsorption, the bacterial cells were washed twice in medium $\mathrm{W}$ and resuspended in $6 \mathrm{ml}$ of prewarmed $\left(30^{\circ} \mathrm{C}\right)$ medium $\mathrm{W}$ (first growth flask). A 50-fold dilution of the first growth flask was made (second growth flask) and the two flasks were then incubated at $30^{\circ} \mathrm{C}$. Then, $100 \mu \mathrm{l}$ samples were taken from the two flasks every $30 \mathrm{~min}$ for up to $8 \mathrm{~h}$ and centrifuged. The supernatants were immediately plated onto heat-shocked spores of $S$. hirsuta NRRL B5792.

DNA purification and analysis. Phage and bacterial DNA purifications were carried out as previously described (Haket et al., 1990). After digestion with restriction enzymes, the DNAs were heat treated $\left(90^{\circ} \mathrm{C}\right.$, $10 \mathrm{~min}$ ) in order to denature the cohesive ends, electrophoresed on agarose gel and blotted onto nitrocellulose membranes, as described previously (Haket et al., 1990). The blots were then hybridized with labelled JHJ-1 DNA (Haket et al., 1990).

\section{Results and Discussion}

\section{The prophage of S. hirsuta 367 UC 8106 is inducible with mitomycin $C$}

Saccharopolyspora hirsuta 367 UC 8106 (and IC-11) has previously been shown to contain possible prophage DNA sequences homologous to phage JHJ-1 DNA (Haket et al., 1990). As mitomycin C induces phages from actinomycetes (Ogata et al., 1985), S. hirsuta 367 UC 8106 was exposed to various concentrations of mitomycin $\mathrm{C}$ and the culture supernatants were plated on the two indicator strains. At mitomycin $\mathrm{C}$ concentrations of $25 \mu \mathrm{g} \mathrm{ml}^{-1}$ or greater, turbid plaques were detected on S. hirsuta NRRL B-5792 and clear plaques on IC-11. The ratio of turbid over clear plaques was in the range of $10^{5}: 1$ after correction for the $10^{4}$-fold restriction on $S$. hirsuta NRRL B-5792 of phage grown on S. hirsuta 367 IC-11 (Haket et al., 1990). Phages from two turbid plaques were amplified on $S$. hirsuta NRRL B-5792: the first, named JHJ-2, formed clear and invasive plaques similar to phage JHJ-1 when replated on B-5792 and the second, JHJ-3, retained the turbid plaque phenotype. Thus, the induction experiment proved that strain UC 8106 does contain a prophage.

It was previously reported that strain UC 8106 does not spontaneously release phage (Haket et al., 1990). However, by using a more sensitive assay, it was shown that old mycelial cultures of strain UC 8106 spontaneously released low numbers of phages. The phages produced turbid self-limiting plaques on $S$. hirsuta NRRL B-5792 and thus resembled phage JHJ-3. In the same assay, strain IC-11 released phage resembling JHJ-1.

In order to determine that the induced phages, JHJ-2 and JHJ-3, were related to JHJ-1, DNA from all three phages was digested with restriction endonucleases. No differences between $\mathrm{JHJ}-1, \mathrm{JHJ}-2$ and $\mathrm{JHJ}-3$ were detected in any of the restriction patterns (data not shown). Thus, all three phages appear to have originated from the same parent phage. The differences in the phenotypes of the three phages therefore appear to be due to short deletions and/or point mutations and not to major deletions.

\section{Phage JHJ-1 can infect phage JHJ-3 lysogens}

To test whether phage $\mathbf{J H J}-3$ is a true temperate phage or not, two JHJ-3 lysogens of $S$. hirsuta NRRL B-5792, 
named S. hirsuta B5792LA and B5792LB, were isolated. Digested DNA of these two strains was hybridized with labelled JHJ-1 DNA and was shown to harbour intracellular phage DNA with the same hybridization patterns (data not shown) as in S. hirsuta 367 IC-11 and UC 8106 DNA (Haket et al., 1990). S. hirsuta NRRL B5792 DNA did not hybridize with phage JHJ-1 DNA.

Strains B5792LA and B5792LB, as well as the natural JHJ-3 lysogens, S. hirsuta 367 UC 8106 and IC-11, were refractory to infection by phage JHJ-3, suggesting that phage $\mathrm{JHJ}-3$ is a temperate phage and that these strains are true lysogens. Phage $\mathrm{JHJ}-1$ produced clear and invasive plaques on both $S$. hirsuta B5792LA and B5792LB as well as in IC-11 but no plaques were detectable in UC 8106. Thus, phage JHJ-1 can infect lysogens, and by analogy to other phage-host systems (Lomovskaya et al., 1980; Johnson et al., 1981), phage JHJ-1 appears to be a virulent mutant insensitive to repression. Since phage JHJ-1 infected all the JHJ-3 lysogens except UC 8106, the lack of sensitivity of UC 8106 may be caused by a block at an early step of infection, possibly at the adsorption level. Attempts to test this hypothesis did not yield reproducible results. The adsorption experiments had to be carried out with mycelial cultures rather than germinated spores since $S$. hirsuta 367 strains did not differentiate sufficiently to yield spore stocks.

Although phage JHJ-2 made invasive plaques on $S$. hirsuta NRRL B-5792, it did not yield plaques on any lysogens and therefore appears to be phenotypically different from phage JHJ-1.

\section{Host range and plaque morphology}

The host range and the plaque morphology of all three phages are summarized in Table 2. The phages differed in their behaviour on the different hosts. Phage JHJ-1 made clear invasive plaques on the $S$. hirsuta strains, $S$. taberi, S. erythraea NRRL 2359 and, in contrast to some of our previous results (Haket et al., 1990), clear selflimiting (approx. $1 \mathrm{~mm}$ ) plaques on $S$. rectivirgula and the other strains of $S$. erythraea. The reason for such discrepancies is unknown since the same phage and spore stock were used for both investigations. Phage JHJ-2 did not lyse $S$. hirsuta 367 IC-11 but otherwise behaved like JHJ-1. The broad host range of phage JHJ1 and JHJ-2 suggests that they could be useful tools in taxonomic investigations of the genus Saccharopolyspora. The host range of phage JHJ-3 was more restricted than phages JHJ-1 and JHJ-2 (Table 2). Turbid self-limiting

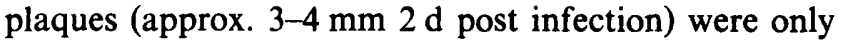
observed on $S$. hirsuta NRRL B-5792, $S$. taberi and $S$. erythraea NRRL 2359. These three phages along with
Table 2. Comparative host range and plaque morphology of phages $J H J-1, J H J-2$ and $J H J-3$ on different actinomycete strains

\begin{tabular}{|c|c|c|c|}
\hline \multirow[b]{2}{*}{ Strain } & \multicolumn{3}{|c|}{ Phage: } \\
\hline & JHJ-I & JHJ-2 & JHJ-3 \\
\hline S. hirsuta NRRL B-5792 & C, I & $\mathrm{C}, \mathrm{I}$ & $\mathrm{T}, \mathrm{S}$ \\
\hline S. hirsuta A1143 & $\mathrm{C}, \mathrm{I}$ & $\mathrm{C}, \mathrm{I}$ & ND \\
\hline S. hirsuta 367 IC-11 & $\mathrm{C}, \mathrm{I}$ & NL & NL \\
\hline S. taberi NRRL B-16173 & C, I & C, I & $\mathrm{T}, \mathrm{S}$ \\
\hline S. rectivirgula DSM 43787 & $\mathrm{C}, \mathrm{S}$ & $\mathrm{C}, \mathrm{S}$ & NL \\
\hline S. erythraea ATCC 11635 & $\mathrm{C}, \mathrm{S}$ & $\mathrm{C}, \mathrm{S}$ & NL \\
\hline S. erythraea NRRL 2338 & $\mathrm{C}, \mathrm{S}$ & $\mathrm{C}, \mathrm{S}$ & NL \\
\hline S. erythraea ISP 5517 & C, $\mathrm{S}$ & $\mathrm{C}, \mathrm{S}$ & NL \\
\hline S. erythraea NRRL 2359 & $\mathrm{C}, \mathrm{I}$ & $\mathrm{C}, \mathrm{I}$ & $\mathrm{T}, \mathrm{S}$ \\
\hline S. erythraea NRRL 2360 & $\mathrm{C}, \mathrm{S}$ & $\mathrm{C}, \mathrm{S}$ & NL \\
\hline S. erythraea IA 3038 & $\mathrm{C}, \mathrm{S}$ & $\mathrm{C}, \mathrm{S}$ & NL \\
\hline
\end{tabular}

Abbreviations: $\mathrm{C}$, clear plaques; $\mathrm{I}$, invasive plaques; $\mathrm{T}$, turbid plaques; S, self-limiting size plaques; NL, no evidence of lysis; ND, not done.

phage SE-6 (Grund \& Hutchinson, 1987) are the only phages that produce a lytic infection in $S$. erythraea NRRL 2359 (Donadio et al., 1986; Grund \& Hutchinson, 1987; Katz et al., 1988; Smorawinska et al., 1988).

The absence of visible plaques on $S$. erythraea strains (except NRRL 2359) and $S$. rectivirgula infected by JHJ3 seems unlikely to be due to a lack of phage adsorption since both phages $\mathrm{JHJ}-1$ and $\mathrm{JHJ}-2$ formed plaques on these strains. It is possible that phage $\mathrm{JHJ}-3$ lysogenized all the cells or alternatively that the plaques were not detectable. However, attempts to isolate lysogens of $S$. erythraea strains (except NRRL 2359) were unsuccessful owing to the lack of visible plaques and to the restriction of phages grown in $S$. hirsuta NRRL B-5792 (unpublished results).

The difference in plaque morphology suggests a genetic basis for the invasive properties of phages JHJ-1 and $\mathrm{JHJ}-2$. We define the $\mathrm{Inv}^{+}$(invasive) phenotype as the ability of phages to grow on old mycelium. Consequently, JHJ-3 is the Inv ${ }^{-}$wild-type phage. The fact that phages $\mathrm{JHJ}-1$ and $\mathrm{JHJ}-2$ both have the $\mathrm{Inv}^{+}$ phenotype, but only phage $\mathrm{JHJ}-1$ is insensitive to repression, suggests that these phages have different mutations. Moreover, the results in Table 2 suggest that the $\mathrm{Inv}^{+}$phenotype is strain-dependent and may be modulated by host cellular function(s).

S. hirsuta NRRL B-5792 is a facultatively thermophilic actinomycete as it can grow at temperatures up to $50{ }^{\circ} \mathrm{C}$ (Lacey \& Goodfellow, 1975). The plaques of phages JHJ-1 and JHJ-2 were more invasive at 43 and $50^{\circ} \mathrm{C}$, respectively, than those observed for incubations at $30^{\circ} \mathrm{C}$. Such behaviour may be due to the higher 


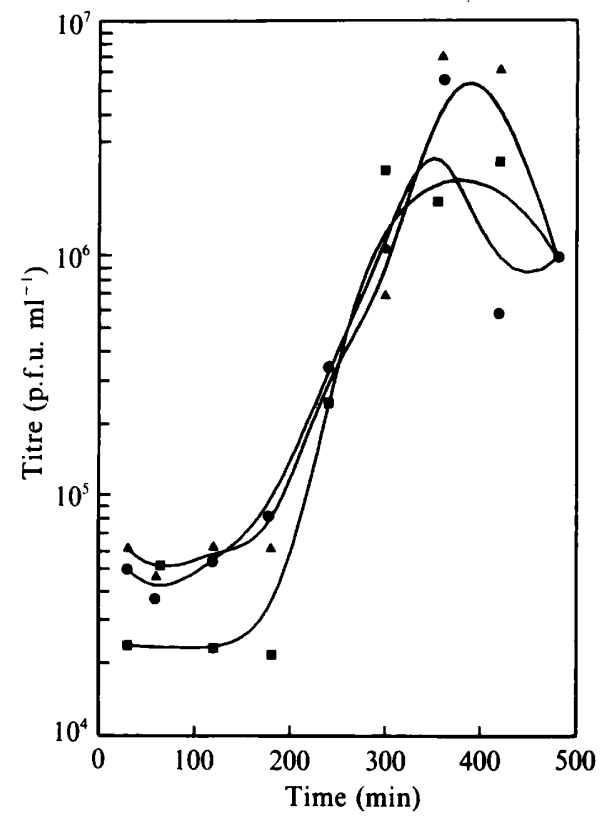

Fig. 1. One-step growth curves of phages JHJ-1 (A), JHJ-2 (O) and JHJ-3 (a) on $S$. hirsuta NRRL B-5792 at $30^{\circ} \mathrm{C}$. These are representative data from one of three experiments.

metabolic rates of cells grown at higher temperatures. At higher temperatures, phage JHJ-3 plaques were still turbid and self-limiting but the diameter of the plaques was larger (approx. 8-9 $\mathrm{mm}$ ). The host range and plaque morphology on $S$. erythraea strains was the same at $43^{\circ} \mathrm{C}$ as at $30^{\circ} \mathrm{C}$.

The reference strains (Table 1), representing genera other than Saccharopolyspora, were refractory to infection by the three phages.

The burst size of all three phages on $S$. hirsuta NRRL B5792 is similar

Phages JHJ-1 and JHJ-2 were shown to produce $\mathrm{Inv}^{+}$ and clear plaques on $S$. hirsuta NRRL B-5792 whereas JHJ-3 plaques were turbid and self-limiting. To determine whether the phenotypic properties of the plaques of the three phages were reflected by differences in their replication cycle, one-step growth experiments were performed on germinated spores of $S$. hirsuta NRRL B5792. There was no significant difference in the respective life cycle of each phage (Fig. 1). The latency and rise periods lasted between 150 and $170 \mathrm{~min}$, and 175 and $235 \mathrm{~min}$, respectively, and the complete cycle lasted approximately $6 \mathrm{~h}$. These periods are rather long compared to those of many actinophages (Lomovskaya et al., 1980). The burst sizes of the three phages ranged from 100-110 p.f.u. per cell. The titre of the three phages decreased slightly after $7 \mathrm{~h}$ post infection. This may be caused by secondary infection by the released phages. Since the invasive property is detectable only on (plated) old cultures, the lack of differences in the burst sizes could be due to the use of young cultures containing germinated spores in the one-step growth experiments.

We wish to thank the Upjohn Company, J. Schneider, A. J. Lyons, D. P. Labeda and J. Lacey for providing bacterial strains; Ryszard Brzezinski and François Denis for discussions, and Pierre Béchard, R. Brzezinski, Danielle Desmarais, Marco Festa-Bianchet and Brian G. Talbot for critical reading of the manuscript and Anne Rousseau for secretarial assistance. This research was supported by grants from the Natural Sciences and Engineering Research Council of Canada and the Fonds pour la Formation de Chercheurs et l'Aide à la Recherche du Gouvernement du Québec to C.V.D.

\section{References}

BrzeziNiski, R., SURmaCz, E., KutNer, M. \& Piekarowicz, A. (1986). Restriction mapping and close relationship of the DNA of Streptomyces erythraeus phages 121 and SE-5. Journal of General Microbiology 132, 2937-2943.

Donadio, S., Paladino, R., Costanzi, I., Sparapani, P., Schreil, W. \& IACCARINO, M. (1986). Characterization of bacteriophages infecting Streptomyces erythreus and properties of phage-resistant mutants. Journal of Bacteriology 166, 1055-1060.

DowDING, J. E. (1973). Characterization of a bacteriophage virulent for Streptomyces coelicolor A3(2). Journal of General Microbiology 76, 163-176.

Grund, A. D. \& Hutchinson, C. R. (1987). Bacteriophages of Saccharopolyspora erythraea. Journal of Bacteriology 169, 3013-3022.

Haket, J., JR, Desmarais, D., MehindaTe, K. \& DéRY, C. V. (1990). Saccharopolyspora hirsuta strain 367 releases JHJ-1, a bacteriophage capable of propagation on old mycelium. Journal of General Microbiology 136, 573-579.

Johnson, A. D., Poteete, A. R., Lauer, G., SAuer, R. T., Ackers, G. K. \& PASTHNE, M. (1981). Lambda repressor and crocomponents of an efficient molecular switch. Nature, London 294, 217-223.

Katz, L., Chiang, S.-J. D., Tuan, J. S. \& Zablen, L. B. (1988). Characterization of bacteriophage $\phi \mathrm{C} 69$ of Saccharopolyspora erythraea and demonstration of heterologous actinophage propagation by transfection of Streptomyces and Saccharopolyspora. Journal of General Microbiology 134, 1765-1771.

KORN-WeNDISCH, F., KEMPF, A., GRUND, E., KROPPENSTEDT, R. M. \& KUTZNER, H. J. (1989). Transfer of Faenia rectivirgula Lacey and Goodfellow 1975, elevation of Saccharopolyspora hirsuta subsp. taberi Labeda 1987 to species level, and emended description of the genus Saccharopolyspora. International Journal of Systematic Bacteriology 39, 430-441.

KURUP, V. P. (1984). Thermophilic actinomycetes: their role in hypersensitivity pneumonitis. In Biological, Biochemical and Biomedical Aspects of Actinomycetes, pp. 145-159. Edited by L. Ortiz-Ortiz, L. F. Bojalil \& V. Yakoleff. London: Academic Press.

LABEDA, D. P. (1987). Transfer of the type strain of Streptomyces erythraeus (Waksman, 1923) Waksman and Henrici 1948 to the genus Saccharopolyspora Lacey and Goodfellow 1975 as Saccharopolyspora erythraea sp. nov. and designation of a neotype strain for Streptomyces erythraeus. International Journal of Systematic Bacteriology 37, 19-22.

LACEY, J. \& GoOdFellow, M. (1975). A novel actinomycete from sugar-cane bagasse: Saccharopolyspora hirsuta gen. et sp. nov. Journal of General Microbiology 88, 75-85.

Lomovskaya, N. D., Chater, K. F. \& Mkrtumian, N. H. (1980). Genetics and molecular biology of Streptomyces bacteriophages. Microbiological Reviews 44, 206-229. 
Ogata, S., Suenaga, H. \& Hayashida, S. (1985). A temperate phage from Streptomyces azureus. Applied and Environmental Microbiology 49, 201-204.

Paulus, T. J., Tuan, J. S., Luebee, V. E., Maine, G. T., Dewitt, J. P. \& KATZ, L. (1990). Mutation and cloning of eryG, the structural gene for erythromycin $O$-methyltransferase from Saccharopolyspora erythraea, and expression of ery $\mathrm{G}$ in Escherichia coli. Journal of Bacteriology 172, 2541-2546.

Pepys, J., Jenkins, P. A., Festenstein, G. N., Gregory, P. H., Lacey, M. E. \& SkINNER, S. A. (1963). Farmer's lung: thermophilic actinomycetes as a source of "farmer's lung hay" antigen. Lancet ii, 607-611.

SCHNEIDER, J. \& KUTZNER, H. J. (1989a). Distribution of homologies among the genomes of several actinophages of Faenia and Saccharopolyspora as determined by DNA hybridization. Interviro$\log y 30,237-240$.
SCHNEIDER, J. \& KUTZNER, H. J. (1989b). Distribution of modules among the central regions of the genomes of several actinophages of Faenia and Saccharopolyspora. Journal of General Microbiology 135, $1671-1678$.

SCHNEIDER, J., GARCIA, I. A. \& KUTZNER, H. J. (1987). Characterization of a family of temperate actinophages of Faenia rectivirgula. Journal of General Microbiology 133, 2263-2268.

SMORAWIǸSKa, M., DENIS, F., DÉRY, C. V., MAGNY, P. \& BRZEZIǸsKI, R. (1988). Characterization of SE-3, a virulent bacteriophage of Saccharopolyspora erythraea. Journal of General Microbiology 134, 1773-1778.

Whaley, H. A., Chidester, C. G., Miszak, S. A. \& Wnuk, R. J. (1980). Nodusmicin: the structure of a new antibiotic. Tetrahedron Letters 21, 3659-3662. 